\title{
The Concept and Classification of Animal Rights: Points for Debating
}

\author{
Aleksey Pavlovich Anisimov* \\ ANATOLIY JAKOVLEVICH RYZHENKOV**
}

\begin{abstract}
This article is devoted to research of philosophical discussions about animal rights which have affected on content of international law and national legal systems. This has manifested itself in the gradually recognition of the rights of wild and domestic animals. The authors provide classification of these rights and, according to criteria of their scope, distinguish three groups of wild animals and seven groups of domestic animals (companions, circus, agricultural, sport, experimental, zoo and service animals). Domestic animals have both vested rights (protection against cruelty and to a favorable environment) and, to a different extent, the right to good treatment, choice of owner, good health (veterinary care), adequate burial and comfortable transfer - these mainly dependent on the owner's goodwill. The article includes evidences that the current situation with a different scope of subjective rights of different groups of animals resembles the situation with a different scope of rights of certain groups of population in the age of feudal fragmentation. The authors also comment about gradual change and future of the situation.
\end{abstract}

Keywords: wild and domestic animals; animal rights; philosophy; legal personality; representation; ownership

\section{INTRODUCTION}

The development of human civilization, particularly in the second half of the $20^{\text {th }}$ century and as a result of the United Nations activities, has been based firmly on the priority of human rights as the supreme value, which determines the essence and content of laws. Nevertheless, the development of the concept of animal rights faces all the same obstacles to the same extent as development of the concept of human rights has passed including skepticism of deputies, state officials, ordinary citizens and representatives of the scientific community. Society's attitude to animals has not been same during different historical periods. The initial worshipping of certain kinds of animals, e.g., the cow in India is still considered a sacred animal has been gradually replaced with complete absence of their rights, with gradual growth of the scope of their legal personality, beginning in the $19^{\text {th }}$ century. Meanwhile, there is historical evidence (mainly in the Middle Ages) of legal proceedings and sentences imposed on wild and domestic animals for various crimes (mainly murders), which indicates rudiments of their legal personality. ${ }^{1}$ The attitude change towards legal personality of animals in developed countries was associated with execution of a number of international agreements on protection of certain species of animals.

* Professor of Civil Law, Volgograd Institute of Business, Doctor of juridical sciences, 400081, Russian Federation, Volgograd, Sofia Kovalevskaya Street, 17 B. E-mail: anisimovap@mail.ru

** Professor of the Chair of Civil and Entrepreneurial Law of the Kalmyk State University, Doctor of juridical sciences, 400001, Russian Federation, Volgograd, Kanunnikova Street, 9-17. E-mail: 4077778@list.ru

1 Frazer (2001). 
For example, in 1875, Austria-Hungary and Italy adopted the Declaration for the Protection of Birds; in 1897 Russia, Japan and the USA concluded an agreement on joint use and protection of seals in the Pacific Ocean. Later claims for humanism and ban on cruelty to animals developed on the basis of the provisions set by these and many other international instruments. However, all legal acts adopted in the 19th and 20th centuries related to local issue and general protection animal rights remained unsystematic for a long time. One exception was the World Charter for Nature adopted by the United Nations General Assembly in 1982. The Preamble stipulates that "every form of life is unique, warranting respect regardless of its worth to man, and, to accord other organisms such recognition, man must be guided by a moral code of action". ${ }^{2}$

The Preamble to the Universal Declaration of Animal Rights of September 23, 1977 states that life is one, all living beings having a common origin and having diversified in the course of the evolution of the species; all living beings possess natural rights, and that any animal with a nervous system has specific rights; the coexistence of species implies a recognition by the human species of the right of other animal species to live.

Nowadays, in many countries, as well as at the international level, there has been significant progress in protection of animal rights, and an analysis of the dynamics of this process only suggests an increase in the extent of the legal personality of various groups of animals in the coming years. However, the skepticism of a most part of the scientific community regarding recognition of legal personality of animals has yet to be overcome. Using historical legal, comparative legal, logical methods, as well as the method of system analysis, trends and patterns of formation of legal personality of wild and domestic animals will be indentified in Russia and a selection of other countries.

\section{WHAT ARE ANIMALS AND THEIR LEGAL STATUS?}

In the Russian Federation, as well as in many other countries, legislation clearly distinguishes domestic and wild animals. Domestic animals are in private ownership and subject to the Civil Code; wild animals are in the state of natural freedom and in the scope of the environmental legislation.

In addition, in Russia there is no clear legal definition of either a generic animal category or a domestic category. The situation with wild animals is rather better. According to Article 1 Law of the Russian Federation "On Fauna" of April 24, 1995 No. 52-FZ, "fauna is a set of living organisms of all kinds of wild animals, permanently or temporarily inhabiting the territory of the Russian Federation being in the state of natural freedom, as well as those related to natural resources of the continental shelf and exclusive economic zone of the Russian Federation". From the following definition proposed in this law, it follows that "an object of fauna is an organism of animal origin (wild animal)". Therefore, wild animals falling under the scope of this law are exclusively mammals but also birds, fish, insects and other life forms. This conclusion is also confirmed by the analysis of the 
Red Data Book of Russia ${ }^{3}$ containing a list of biological species under special state protection. $^{4}$

A similar approach is also applied in laws of other former USSR countries. For example, Law of the Kyrgyz Republic “On Fauna” of June 17, 1999 No.59 provides the following definition: "Fauna is a legally protected natural object which includes insects, reptiles, wild animals, birds, fish and other aquatic animals being in the state of natural freedom and fulfilling environmental, cultural and recreational functions". Hence, it follows that, unlike Russia, in the Kyrgyz Republic insects, birds, fish and other objects are officially included in the objects of fauna.

The situation with domestic animals lists is considerably worse in post-Soviet countries. The Law of the Russian Federation "On Veterinary Medicine" of May 14, 1993 (Article 1), considering the objectives of veterinary science, mentions "agricultural, domestic, zoo, fur and other animals, birds, fish and bees". A more detailed list of domestic animals can be observed in Article 1 Law of Ukraine "On Veterinary Medicine" November 16 2006, in which species of animals are given as mammals, poultry, birds, bees, insects, fish, crustaceans, molluscs, frogs, amphibians and reptiles. Thus, Ukraine, in contrast to Russia, includes domestic animals in the scope of veterinary medicine include reptiles, insects and some types of water bioresources. It appears that Russian classification is less appropriate, as it blends the species of animals and the patterns of their use (agriculture, zoo), which is not correct.

One of few attempts in the post-Soviet region to combine wild and domestic animals in one group is the Law of Ukraine "On Protection of Animals against Cruelty" of February 21, 2006. According to Article 1 of this law, animals are biological objects relating fauna: agricultural, domestic, wild, including poultry and wild birds, fur, laboratory, zoo and circus ones. It appears that, from the point of view of protection of animal rights, this is an optimal approach by combining them all into one group. However, in contrast to lawyers, biologists pay attention to other aspects in defining animals.

In biology, animals are understood as a kingdom of living organisms and one of the largest subdivisions in the system of organic world. Animals have ready organic substances, in contrast to most plants. Other important peculiar features of animals are active metabolism and, therefore, limited growth of the body, as well as development of different functional organ systems in the course of evolution: muscular, digestive, respiratory, excretory, reproductive, circulatory, and nervous. The ability to perceive stimuli and react to them (due to emergence of the nervous system) caused formation of sense organs. In biology, animals are divided into vertebrates and invertebrates. ${ }^{5}$

3 The Red Data Book of the Russian Federation is a list of rare and endangered species (subspecies, populations) of wild animals inhabiting the territory of the Russian Federation, the continental shelf and the exclusive economic zone of the Russian Federation. The Red Data Book of the Russian Federation is an official document containing data on these objects of fauna as well as necessary measures for their protection and restoration. Wild animals listed in the Red Data Book of the Russian Federation are subject to special protection. Their withdrawal from the natural environment is allowed in exceptional cases. The Criminal Code of the Russian Federation provides for more stringent sanctions for illegal hunting or other withdrawal of fauna objects listed in the Red Data Book of the Russian Federation.

${ }^{4}$ Order of the State Committee for Environmental Protection of the Russian Federation of 19.12.1997.

5 Biological Encyclopedic Dictionary at link 1. 
Therefore, the differences of the "biological" and "legal" classifications is that biologists do not focus upon on the nature of use of objects of fauna (agricultural, circus and other animals), which is important only for enshrining animal rights in regulations, but on differences of animals from other forms of life as well as interspecies differences (availability or lack of nervous system, vertebral column, etc.). This arises from the goals and objectives of biological science, which is not interested specially in peculiarities of use and protection by man of certain species and groups of animals.

This overview shows that wild and domestic animals have more similarities than differences. Moreover, a "wild" bear or a tiger sitting in a cage in a zoo or a circus is a domestic animal, in private ownership and fall within the scope of the Civil Code but not environmental legislation. Moreover, if such an animal manages to escape to freedom, it again acquires the status of an object of fauna falling within the scope of environmental legislation.

In this regard, the differentiation of animals as "wild - domestic" but also as "animals - birds, reptiles, insects, and fish" seems rather more logical in terms of subjective rights of animals. Therefore, for the purposes of this article, animals will be considered as terrestrial vertebrate mammals which have a mind and a nervous system and fall within the scope of both civil and environmental legislation.

\section{PHILOSOPHY OF ANIMAL RIGHTS}

The legalization of animal rights is affected by the philosophical discussions regarding attitude to animals. This has been going on for several centuries and Thomas Hobbes (1588-1679) and René Descartes (1596-1650) were among the first who raised this issue in their works. Thomas Hobbes believes that man shares a sensuous nature with animals. The main difference between men and animals is our invention of words and speech. It is language that makes man special. Language enables men to create the special agreement which Hobbes calls the social contract. However, language is more than a contract-enabler. The concepts of true and false come with the use of words - correctly or falsely. Thus animals are not concerned with truth or falsehood. Deliberation is the process of choosing between various appetites that cannot be satisfied at the same time. This alternate succession of appetites, aversions, hopes and fears, is no less in other living creatures than in man and therefore animals also deliberate. Animals, as well as men, have will. Every voluntary act is that which follows from the will, so animals have some reason, they are deliberative beings with a will, and have the ability to act voluntarily. Animals should be treated as "children, fools and madmen" and appoint guardians, or curators which should represent them when the social contract is formed. ${ }^{6}$

In the philosophical system of René Descartes, the animal's ability to feel pain is denied. According to Descartes, to feel the pain, one needs to have a mind which animals, in his opinion, do not posses. Today, fortunately, very few continue to deny that animals can feel pain. Although experiments on animals still take place including the practice of vivisection, statutory rules, at least, recognize the obvious fact that animals are capable of experiencing pain and suffering. ${ }^{7}$

${ }^{6}$ Hobbes (2016) at link 2; Sætra (2014) 177-93.

7 Descartes (1996), Branham (2005), Cottingham (1978). 
While Kantianism has been an ethical background for the movement for animal rights for many years, Immanuel Kant (1724-1804) himself certainly did not think that people should have ethical responsibilities to animals. While Descartes's insensitivity to suffering of animals results from his point of view that animals can not feel pain, Kant believes that animals do not possess rationality. Kant believes that rationality, which he reserves for people, involves some level of consciousness. Denying that animals have this mental ability, Kant mixes them with simple things, saying that can be disposed of whenever wanted or needed. However, Kant, at the same time, does not call for everyone to do so immediately. ${ }^{8}$ Kant assumes that cruelty to animals is bad only because it causes harm to mankind. People have obligations only to other people and cruelty to animals contradicts the obligation of man to himself because it kills sympathy for suffering of others, which is very useful in relationships with other people. Hence, it follows that the ban on causing suffering to animals is based on the moral principles of mankind rather than on provision of animals with powers of people. ${ }^{9}$

Jeremy Bentham made a great contribution to the theory of protection of animal rights (1748-1832) and is often called the "first patron of animal rights". In contrast to Descartes, Bentham admitted the existence of suffering of animals, though they are not capable of reasoning. Meanwhile, infants have no such ability but no one has ideas of depriving them of legal protection. Bentham admitted that animals may be slaughtered for use of their meat for food, providing that animals do not suffer unnecessarily. In this regard, Bentham believed that animals could be used in medical experiments but only provided that these experiments have a certain purpose - the benefit of mankind and the chances of achieving this purpose are very high. ${ }^{10}$

The fundamental contribution of David Hume (1711-1776) in the philosophy of animal rights consists in the idea that animals, like humans, can learn from experience, if they make a conclusion that the same events can result from the same cause. According to this principle, they gradually accumulate knowledge about external objects and this is why a horse can never jump to a height exceeding its powers and abilities. It is even more obvious in cases of maintenance of discipline and training of animals that, through the proper application of rewards and punishments, can be involved in the implementation of any actions, sometimes even against their natural instincts and inclinations. A typical example of the effect of experience on the actions of animals is the situation when a dog understands that a raised whip may entail pain. However, animals receive more knowledge from the hereditary instinct than from experience, and in this sense is similar to humans. ${ }^{11}$

A radical turn in discussions on animal rights occurred in the 1960s with formation of the modern concept of ecophilosophy. In The Rights of Animals Brigid Brophy states that "the relationship of homo sapiens to the other animals is one of unremitting exploitation." 12 We employ their work; we eat and wear them. We exploit them to serve our superstitions: whereas we used to sacrifice them to our gods and tear out their entrails in order to foresee the future, we now sacrifice them to science, and experiment on their entrails in the hope - or on the mere off chance - that we might thereby see a little more clearly into the present". Since the mid-1970's, such prominent ecophilosophers as S. Wise, D. Favre,

\footnotetext{
8 Kant (1978), Branham (2005).

9 Kant (2000).

10 Bentham (2007) 43.

11 Hume (2006).

12 Brophy (1965).
} 
R. Ryder, P. Singer, T. Regan, A. Linzey, K. Stone, as well as many professional lawyers, have been paying attention to protection of animal rights and wildlife.

In his books, S. Wise asserts that the status of "property" first must be canceled for particularly clever animals, such as chimpanzees and bonobos, due to the increased evidence of their ability to "practical autonomy". According to Wise, these animals are functionally similar to children and incapable adults and should also be granted fundamental legal rights as men. ${ }^{13}$ Professor David Favre thinks that, even without cancellation of the status of property, animals should be granted the status of plaintiffs in cases of violation of their statutory rights. ${ }^{14}$

T. Regan notes that the relationship between man and animals are exploitative in many respects. Meanwhile, animals have the right to satisfy their needs and achieve their natural goals. They should also have rights as animals have a moral status. The moral status of animals follows from recognition of their individual inherent value which does not depend on their benefit for man. Regan makes an objection against the statement about the importance of differences in the legal status of man and animals, pointing out changeability of legal rules. People and animals are living beings that have an equal innate value. People have obligations for non-intervention and prevention of harm to animals. Meanwhile, implementation of the concept of Regan will mean vegetarianism because people have alternative sources of food; a ban on hunting and animal experiments and, apparently, most other types of use of domestic animals, except for companion animals. Another issue associated with Regan's theories is that conflicts often arise between people and animals having an innate value and having competing demands of rights. ${ }^{15}$

P. Singer is the author of the theory of moral philosophy which implies equal respect for the interests of people and animals. According to this theory, something that is bad for mankind is also bad for animals. Although murder may be resorted with the purpose to survive, we do not need to kill animals. Singer spits out a scathing reproach to mankind - if there is a conflict of interests of man and animal, the interests of animals are neglected e.g., life-long suffering of animal, and gastronomic tastes of man. Singer believes that the issue of liberation of animals is a part of the wider and more global issue of justice and moral existence. He believes that the movement for protection of animals will lead to higher ethical consciousness - liberation of animals means liberation of mankind. ${ }^{16}$

Opponents of the concept of animal rights argue that animals should not be counted as persons because they lack the capacity to exercise autonomy and moral choice and a sufficiently sophisticated intelligence. However, these very same points could be made with respect to severely mentally disabled (incapable) people and very young children, who can not exercise their rights. Moreover, some research is revealing that animals are much more similar to humans in their analytical and emotional capacities, as well as in many more respects than previously thought. ${ }^{17}$

Other opponents of the concept of animal rights believe that animals can not be guided by morality or conclude any social agreement, therefore, they can not possess rights. Rights are a part of the social contract which makes no sense without duties. This is the reason for the conclusion that the parallels with the abolition of slavery made by the movement for

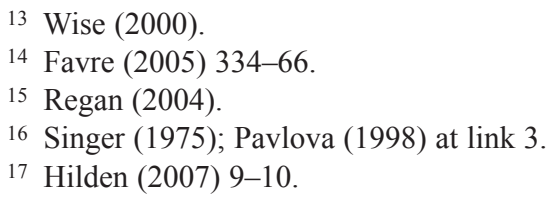


animal rights are outrageous because slaves could and should become full members of society whilst animals cannot under any circumstances. ${ }^{18}$ However, we find these objections debatable. It appears that there is currently an anthropocentric view of animals being subordinate to men and intended for provision of food, aesthetic and other conveniences. A very different conclusion can be made if this issue is addressed from a non-anthropocentric point of view. In this case the moral character of requirements for maintenance and protection of the physical integrity of a number of animals can be seen, which has moral significance and requires settlement of a great number of legal questions concerning the integrity and protection of their bodies. ${ }^{19}$

In Russian public opinion, it is often observed that the argument that one of the main differences between man and animal is availability of the value of animal and that man is, accordingly, invaluable. Meanwhile, implementation of the provisions of the legislation, e.g., Article 1088 of the Civil Code of Russia, which stipulates compensation for harm to persons who suffer loss as a result of the death of the breadwinner, in judicial practice, leads to accrual of specific amounts of money paid to relatives of the deceased citizen. Moral qualities of animals can hardly be doubted. There are enough examples when animals bring up other species treating them as their own children. In this regard, the story of Mowgli by Rudyard Kipling is a "slice of life". Drawing an analogy with man, it shows that in adopting an orphan people just following instincts? Many animals are not indifferent to what happens to them. To the contrary, they suffer joy and pain like humans. They want their offspring to thrive; they want to be warm and sheltered and fed and they want to avoid predators. This is the reason to imagine oneself as a cat, a dog, or a horse, and to imagine the desired legal system if one were in that position. ${ }^{20}$

This overview has showed that the issue of animal rights gradually occupies more and more space in philosophy, arguments in favor of expansion of animal rights have become more detailed and substantial over the years. Today it cannot be denied that some animals feel pain; have a developed nervous system and experience a complex set of feelings, including those of moral character. The issue of recognition of animal rights is beyond the law itself and it has a moral and psychological nature. Significant changes in social psychology and morality of human civilization of recent decades have already led to the first attempts to legitimize animal rights in constitutions and national laws, in which the emphasis is made on various aspects of humanism.

\section{CONSOLIDATION OF ANIMAL RIGHTS IN INSTITUTIONS AND LAWS}

Legal regulation of protection of animals implemented both at the international and national levels, which can be observed in constitutions of different countries. Generalizing this dynamics, a number of trends in this process from the point of view of approaches of the legislative technique will be highlighted.

1) In the first group of countries the state sets general duties of careful attitude to fauna; ${ }^{21}$ cares about protection of animals and prohibits "impoverishment of fauna", ${ }^{22}$

18 de Waal (1999).

19 Regan (2004) 12-3.

20 Hilden (2007).

21 Article 48 of the Constitution of the Kyrgyz Republic, 2010.

22 Article 54 of the Constitution of the Republic of Lithuania, 1992. 
guarantees protection of species of wild animals "prescribed by law",23 takes valuable species of plants and animals under protection, without specifying whether they are wild or domestic. ${ }^{24}$ The Interim Constitution of Nepal, 2007 refers to special protection of rare species of wild animals and measures for protection of the biological diversity.

2) In the second group of countries, there are detailed requirements for protection of animals along with general regulations on protection of flora and fauna. These countries prohibit practical activities that threatens the ecological functions of flora and fauna causes their attenuation or leads to cruelty to animals. ${ }^{25}$ In a similar way, cruelty to animals is expressly prohibited in the Constitution of India, 1949 (Article 17) with the protection of wild animals and birds is mentioned separately.

3 ) In the third group of countries, there are specification of powers of the central government and the provinces in terms of treatment of both wild and domestic animals. These measures include protection of nature and capture of wild animals, as well as organization of campaigns regarding the medical and sanitary state of animals, arrangement of laboratories, clinics and dispensaries for animals, ${ }^{26}$ according to Article 72 of the Charter of the Republic of Slovenia, 1991, "animals are protected by law from tortures" (i.e. all animals, both wild and domestic). In Article 166 of the Federal Constitution of Malaysia, 1957, the joint jurisdiction of the Federation and the states includes "protection of wild animals and birds" and "animal husbandry; measures for prevention cruelty to animals; veterinary services, quarantine of animals". Thus, from the context of this article of the Constitution of Malaysia, it follows that prohibition of cruelty to animals refers only to domestic animals.

However, the largest scope of animal rights is enshrined in Article 80 of the Federal Constitution of the Swiss Confederation, 1999. According to this article, the Union shall issue regulations on protection of animals and controls: animal management; experiments on animals and interventions in live animals; consumption of animals; import of animals and animal products; trade in animals and their transportation; killing of animals.

It is impossible to trace the dynamics of implementation of constitutional provisions in the sectoral legislation of all countries of the world in a single article, so a number of circumstances important in terms of protection of animal rights will be explored.

In most European countries (Germany, Austria, Switzerland, etc.), animals are not recognized as common things and their legal status is determined by special laws. Second, many countries of the world have adopted special laws on protection of animal rights. Law of Ukraine "On Protection of Animals against Cruelty" of February 21, 2006, No. 3447-IV stipulates their right to life, humane treatment, protection against cruelty, the right to security, veterinary aid and euthanasia. In the Law of Ukraine, a comprehensive approach to treatment of animals and their protection against cruelty is applied and for the first time, a comprehensive legal framework for the activities of public authorities, law enforcement agencies and public organizations in the field of protection of animals against cruelty is established.

Attempts to adopt similar laws were made in Russia as well. In 1999, the State Duma adopted a bill of Federal Law "On Protection of Animals against Cruelty" in three readings.

23 Article 39 of the Constitution of the Republic of Azerbaijan, 1995.

${ }^{24}$ Article 9 of the Constitution of the People's Republic of China, 1982; Article 52 of the Charter of the Republic of Croatia, 1990.

25 Article 225 of the Constitution of the Federal Republic of Brazil, 1988.

26 Article 204 of the Constitution of the Democratic Republic of Congo, 2005. 
However, in January 2000, it was rejected by the President of the Russian Federation, V.V. Putin, who considered that it did not have its own scope and standards stipulated thereby had been already included in other laws. At the time of writing this article, the State Duma of Russia is discussing Bill No. 458458-5 "On Responsible Treatment of Animals", but the final decision is unclear.

Thus, consolidation of animal rights in constitutions and laws is not associated directly with the level of development of economy and democracy in one or another country. It is more probable that this is caused by a more comprehensive set of cultural, historical and ethical reasons effecting legislator's decisions and certain regulatory wordings.

\section{LEGALLY SIGNIFICANT CLASSIFICATIONS OF ANIMAL RIGHTS IN TERMS OF THE LEGISLATION OF THE RUSSIAN FEDERATION AND SELECTED OTHER COUNTRIES}

Russia and most of other post-Soviet countries clearly distinguish legal personality of wild and domestic animals. The principal difference is that domestic animals (as well as captured wild animals equated to them - in circuses, zoos, etc.) are subject to civil law - a special kind of property with some specific features, usually privately owned. Wild animals are governed by the environmental legislation and formally, by virtue of Article 4 of the Law "On Fauna", owned by the state. This approach, however, faces strong criticism by Russian scientists, who note that in respect of fauna objects agencies of state power can not exercise possession as the owner's representatives, because they know neither the exact number of wild animals nor their location. Therefore, it is proposed to create a new legal framework "property of peoples" which does not imply relationships of ownership to wild animals. ${ }^{27}$

In addition, both groups of animals have the same certain legal rights, however, as well as a number of significant differences. It should be noted that the law stipulates general mandatory rights for wild animals, while for domestic animals, along with general mandatory rights, it stipulates also rights related to the good will of the owners but the law does not always insist on enforcement of these rights. The availability of vested rights for both categories of animals confirms the thesis about their general legal regime and legal community of measures for protection of animals of all groups.

\subsection{Vested Rights of Wild and Domestic Animals}

The main vested right of all wild and domestic animals is the right to protection against cruelty, the "right to humane treatment". In the Criminal Code of the Russian Federation, this issue is covered by Article 245 "Cruelty to animals", which refers to acts resulting in death or injury, if committed from hooliganism or mercenary motives, or with the use of sadistic methods, or in the presence of minors. Meanwhile, cruelty to animals not resulting in their death or injury is still beyond criminal or administrative liability, which a number of scientists propose to correct by means of changing the law. ${ }^{28}$ It is notable that the Criminal Code makes no distinction between wild and domestic animals, considering the prohibition of cruelty to animals universal. This leads to the right to protection against cruelty (right to humane treatment) vested for all groups of animals.

27 Petukhova (2015).

28 Bocharov (2014). 
Another general right of all species of animals and man is the right to a favorable environment. Undoubtedly, in laws and international treaties, this animal right is not directly stipulated. However, taking into consideration that polluted air, low-quality water, elevated levels of radiation and other types of negative impact have a devastating effect not only on man but also on animals, this rules should be applied to them as well. Therefore, a regulatory clarification that "collectively means together with animals" is needed.

\subsection{Rights of Domestic Animals}

The rights of domestic animals, in many aspects, are dependant on will of the owners. The law only determines (not always consecutively) their general outline.

1) The right to good treatment (food, care). At first sight, care and good treatment of a domestic animal is manifestation of love for it and such feelings are not regulated by law. Meanwhile, according to Article 241 Civil Code of the Russian Federation, in cases when the owner of domestic animals treats them in a way clearly contrary to the rules established on the basis of law and the norms of humane treatment of animals accepted in society, these animals may be withdrawn from the owner by means of their redemption by a person filing a corresponding claim in court. The redemption price is determined by agreement of the parties, and in case of a dispute - by the court.

Similar rules are also included, e.g., in Article 242 Civil Code of Belarus. Hence, it follows that this right differs from the vested right to protection against cruelty and depends on the owner's will. In addition, civil legislation protects animals against more significant violations of this right by an unconscientious owner.

These rules, despite their humanitarian focus, cause a number of critical comments. A person who wants to rid an animal of ill-treatment out of pity and compassion, is initially in the situation which is unjust for this person, since he has to pay sometimes a considerable amount, in case of pedigree animals, to the person who is, in fact, the offender, while the animal should be withdrawn by the competent authorities forcibly.

A variety of this animal right is the right to live together with the owners. Currently in the whole post-Soviet region, there is no explicit prohibition and responsibility for the owner's expulsion of pets. In some European Union countries and the United States, there are special rescue centers and shelters for animals, along with the same rescue centers for people (the poor and the homeless).

2) The right to choose an owner. According to Articles 230-231 Civil Code of the Russian Federation, a person who finds stray cattle (agricultural animals) or other domestic animals (they can be companion animals, cats or dogs) is obliged to notify the police or local authorities and take them temporarily to their place. If within six months the owner is not found, this person acquires the right of ownership to them. In the case of the appearance of the former owner (after the right of ownership the new owner comes into force), the latter shall be entitled to claim for their return in the circumstances indicating preservation of affection of these animals to him or the new owner's cruelty to or other improper treatment of them. This entails the legally established right of animals to choose an owner which is not absolute or vested and is associated with some additional conditions e.g., escape from the former owner; detection of animal by another citizen; his decision to take the animal to his place; good treatment of them; detection of the animals by the former owner and his claims to the new owner; an experiment concerning the option of one of the two owners, the court's decision enshrining this choice of animals. It is fundamentally important that the legislator regularizes not only the presence of emotions and mind for the 
animals but also the will to choose an owner. These rules are also common in other postSoviet countries. ${ }^{29}$

3) The right to health and veterinary aid. These rights, exercised at will of the owners through a special network of veterinary clinics are assigned most consistently to agricultural, zoo and circus animals. Courts applying the rules of the veterinary legislation point out the duty of owners of these animals to take measures for prevention of animal diseases, including fulfillment of instructions of the competent authorities on isolation of animals with signs of illness, on thorough mechanical cleaning of premises for animals from manure, litter and fodder residues; on disinfection of premises. ${ }^{30}$ The guarantee of the right to health (veterinary aid) is establishment in many countries e.g., Russia, of administrative responsibility of animal owners for concealing information about sudden mortality or simultaneous mass diseases of animals In addition, criminal liability is already stipulated for violation of veterinary rules which causes spread of epizootic diseases by recklessness.

4) The right of domestic animals to burial. This case includes mainly companion animals (cats, dogs, etc.), since special rules apply for agricultural or experimental animals. In Russia, owners independently burying deceased animals in nearby forest belts are a common practice, especially because the vast dimensions of the country make it possible despite Russian law prohibit such actions. For example, according to item 4.1.11 Decision of the Council of Deputies of the urban settlement of Zaprudnya of Taldomsky District of Moscow Region of 26.06.2014 No. 35 “On Approval of Rules of Treatment of Domestic Animals and Control of the Number of Stray Animals in the Territory of the Urban Settlement of Zaprudnya", it is prohibited to bury dogs and cats in the areas surrounding houses, in public gardens, boulevards, park areas, in the territories of institutions and their surrounding areas. Because of such bans, special cemeteries for domestic animals, where they are buried in a decent way at the owners' will, have been spreading in Russia in recent years (City cemetery for animals 2016).

In our view, the emergence of such "cemeteries for domestic animals" can not be connected with the aim to ensure sanitary and epidemiological welfare of man. The fact is that in order to solve a purely medical issue of burial of dead animals it would be enough to organize a common animal burial site far from a settlement. This is exactly how the burial of cattle, for example, as a result of diseases occurs. However, in case of companion animals, it is observed that there is obvious humanization of the burial procedure associated with creation of special cemeteries for domestic animals. In this case, there is a slow turn in the public consciousness of Russians starting to perceive animals to which they are very close not simply as "movable things" but as a special object of legal relations requiring special treatment (and, accordingly, special rights).

5) Animal rights under the transport agreement. The European Convention for the Protection of Animals during International Transport (1968) defines the general terms and conditions of the international transport of animals, preparation for transport, vehicles requirements, the degree of comfort of the transport for animals, requirements for veterinary inspection, certification and specification of the terms and conditions of different types of transport - by road, by sea and by rail. Many countries have adopted similar regulations at the national level.

${ }^{29}$ Art. 183-184 Civil Code of Armenia, Art. 231-232 Civil Code of Belarus; Art. 262-263 Civil Code of Kirghizia.

30 Appellate Decision of Altai Krai Court of 04.12.2013. 
For example, in Russia, there are Rules of Transport of Animals by Rail approved by Order of the Ministry of Railways of Russia of June 18, 2003, No. 35. According to this bylaw, clean and washed cars shall be provided for loading of animals with washed and disinfected vechiles for loading of pedigree, zoo, circus animals and animals for export, competitions and exhibitions; loading and unloading of animals shall be performed during daylight hours; it establishes the maximum number of cattle for transport in one car, as well as special rules for arrangement of certain types of animals (for example, horses). For nonfulfillment of these rules and, therefore, the rights of animals to comfortable transport, the guilty persons are brought to responsibility for violation of the veterinary rules.

\subsection{The classification of Domestic Animals in Terms of Their Rights}

At the moment Russia has no official (regulatory) classification of domestic animals or their rights. The non-binding Model Law of the Commonwealth of Independent States (CIS) "On Treatment of Animals" of October 31, 2007 mentions domestic animals, companion animals, animals used in cultural and entertainment activities, service animals, laboratory animals and wild animals (Article 1). Using this classification as a basis, the following groups of domestic animals with the discordant scope of their legal rights can be derived.

1) Circus animals. Their legal status implies exercise of the right to shelter (even if it is a cage, but in a warm house), food, prohibition of cruelty causing death. In contrast to agricultural animals, they are not consumed. Along with other large animals, they have the right to a certain level of comfort during transport and the right to health care (veterinary aid). Exercise of all these rights is the objective interest of the owner of the circus where these animals are kept.

Meanwhile, some examinations of the state of circus animals show numerous violations of the above mentioned rights. These violations include keeping animals in small cages and crates, where they can not feel free and make enough movement; they often die from intensive training; the training itself is often accompanied by pain and suffering; during transport the owner sometimes tries to save money and violates veterinary rules, which causes death of the animals. ${ }^{31}$ Moreover, it is noted that when an old animal can not bring profit for the circus, the circus often sells it "for hunting" allowing to kill the tame animal near the circus. Because of these reasons, a number of animal protection organizations in the USA are against any use of wild animals in circuses paying attention to the cruelty to them during keeping and performing. ${ }^{32}$

2) Agricultural animals (in case of "good will" of the owner) have the right to shelter, sufficient food, veterinary aid, and in certain circumstances, also at the owner's option and transport in comfortable conditions. If someone tries, from hooliganism, sadistic or other motives as a result of cruelty to an animal (a cow grazing in the meadow), to cause injury or death to this animal, the guilty person will bear responsibility according to Article 245 Criminal Code of Russia. Meanwhile, many breeds of agricultural animals are bred with the purpose to use their meat for food, and therefore, the right to life of this animal category is not guaranteed (in contrast to, for example, circus, zoo or companion animals, which are not consumed). That is why the legislation is focused on keeping and humane killing of these animals.

31 Garrison (1998).

32 Neumann (2014) 167-9. 
The European Convention for the Protection of Animals Kept for Farming Purposes (1976) is an example of such laws. This law formulates the principles of maintenance, care and arrangement of animals on farms, including in terms of intensive animal breeding. In addition, the EU adopted specific directives for farms stipulating the order of maintenance of certain species of animals on these farms. The countries of the Customs Union apply technical regulation "On Food Safety", according to which slaughter of farm animals shall be performed in ways that ensure humane treatment. The Russian Law "On Veterinary Medicine" stipulates creation of favorable conditions for maintenance of animals and animal production, for prevention of environmental pollution with agents of contagious animal diseases, regulates nutrition, watering, transport and vaccination of agricultural animals.

The fulfillment of statutory rules of maintenance and humane slaughter of agricultural animals in most countries of the world faces various difficulties. The main problem is that for costs reasons agricultural animals are kept very crowded, in small cages or pens, with the use of chains and other accessories, which makes animals experience pain and suffering (Lovvorn 2006). This leads to the need for national minimum standards of arrangement of rural animals on farms which protect their rights (as it was done in Switzerland). The researchers also point out problems of nutrition and timely veterinary care of sick animals. ${ }^{33}$ The problem of inhumane slaughter of productive animals should be mentioned separately, even in countries where this measure is expressly prohibited by law. Breeding animals occupy a special place among agricultural animals the used for special high-yield livestock breeding, preservation of the gene pool of small and endangered breeds of agricultural animals useful for selection purposes. These animals are kept in better conditions and receive better nutrition and veterinary aid. Their life is much longer than that of common animals on farms.

3) Experimental (laboratory) animals have the right to shelter and sufficient food, veterinary aid and humane treatment in the course of experiments. Like agricultural animals they, in most cases, do not have the right to life. Animals as objects of experiments are mainly used in medicine and biology. This includes derivation, production, determination of quality, effectiveness and safety of modern medicine, food products and some other substances with the aim to prevent their possible adverse effects to health and life of man, animals or plants. Use of experimental animals often causes them pain, suffering, anxiety or serious body injuries threatening life or being the direct cause of their death. There are cases when preparation of the experiment itself is not of enough sufficient quality which leads to senseless death of animals. ${ }^{34}$ This is the reason why most developed countries of the world enhance the ethical and legal basis of humane treatment and use of laboratory animals.

4) Companion animals (cats, dogs, etc.) constantly live and travel with people. They have the widest scope of legal rights. They have the right to life (they are not consumed and almost not used for experiments); shelter; sufficient food; veterinary aid; it is easier for them to escape from a bad owner and exercise their right to choose the owner. In contrast to other animals, they are not kept in narrow cages, not subject to training (not all dogs are trained). Many cats have the right to freedom of movement, which is not granted to all other domestic animals. Violation of their rights may relate to owners having these animals sterilized, concentration of an excessive number of animals in one apartment, as well as the expulsion of these animals.

33 Satz (2009) 97-8.

34 Thomas (1986). 
The European Convention for the Protection of Pet Animals (1987) includes general basic standards of treatment of pet animals and maintenance of animals, provisions on protection of pet animals against cruelty, order of creation and maintenance of shelters for homeless and abandoned animals, order of purchase of animals and their maintenance. The Convention establishes rules of sale of pet animals and peculiar features of control of the amount of homeless animals. At the national level, most countries have adopted rules of maintenance of dogs and cats stipulating the order of their walking, registration, etc.

5) Zoo animals. They have the right to life, sufficient food, shelter, veterinary aid, comfortable transport. Several zoos have practice of releasing their born animals to the wild. ${ }^{35}$ The main problems here are associated with lack of movement causing suffering of energetic animals (especially elephants, which requires special trainings). There are a number of cases of cruelty to animals in zoos, keeping them in small cages. There are also incidents of killing old zoo (as well as circus) animals in terms of "canned hunts". ${ }^{36}$

6) Service animals. They mainly include border and police dogs that have special patrol or escort functions. They have the right to life; sufficient food (regulated in Russia by special orders of the Ministry of Internal Affairs); veterinary aid; to shelter. Guarantees of the right of service dogs to life (in particular, in the USA) consist in legislative establishment of measures of increased legal liability for killing or causing harm to a police dog, for example, during detention of a criminal. Moreover, such measures may vary in different states. ${ }^{37}$

7) Sport animals (horses, race dogs). They have the right to life; to shelter; to sufficient food; to veterinary aid; to comfortable transfer. In addition, they, along with circus and service animals are subject to full-scale training, which may lead to pain and suffering for them. As a result of training horses are often reported to have various injuries and mutilations. Laws of most countries prohibit use of certain drugs (doping) during competitions of animals, some kinds of sporting events involving animals are officially banned in many countries. In particular, cockfighting is banned both in Europe and the USA. The ban on fighting involving animals is one of the guarantees of exercise of rights of domestic animals to life and health. The main threat to dog fighting consists is that children watching them come to the conclusion that violence is normal. Their sensitivity to suffering systematically reduces, and, ultimately, they often become criminalized. ${ }^{38}$ Society strongly condemns this, while dog racing is allowed in many states of the USA (for example, in the State of Massachusetts), though this is also a form of cruelty to animals.

Thus, the legal category "domestic animals" includes both "classical" tame animals (cats, dogs, cows, sheep, etc.) and wild animals held in captivity (circus, zoo). A common feature of all the groups is private ownership in most cases (though, undoubtedly, a municipal zoo is also possible) and a set of basic rights (to humane treatment, to favorable environment). The rest scope of rights significantly differs even in terms of the main right of animals - the right to life. Being guaranteed for sport, service, companion, circus and zoo animals, it does not belong to agricultural and laboratory animals by virtue of law. The analyzed animal rights are enshrined to a different extent and with unequal specification in various countries of the world and in some national regulatory acts (Directives of the European Union).

\footnotetext{
35 Haas (2015).

36 Grech (2004).

37 Scheiner (2001) 141-4.

38 Gibson (2005).
} 


\subsection{Rights of Wild Animals and Their Classification}

Like domestic animals, legal personality of wild animals varies greatly according to their belonging to one of three groups.

1) Wild animals listed in the Red Data Book or inhabiting specially protected natural areas. The Red Data Book is a register which includes various species of animals and plants. It is prohibited to destroy these species; to use them for creation of private collections; to intervene in their natural living environment in case of economic or other human activities. The Red Data Book may be of three levels (for Russia): IUCN Red List; Red Data Book of the Russian Federation; Red Data Book of constituent entities of the Russian Federation.

Animals included in the Red Data Book of any level (or inhabiting specially protected natural areas with a strict legal regime of bans and restrictions of economic activity, e.g, in reserves) have the widest scope of legal rights among all other categories of wild animals. The right to life is the predominant right among these rights. Hunting for these types is strictly prohibited. Moreover, along with the general components of crime against animals (prohibition of cruelty, Article 245), the Criminal Code of the Russian Federation stipulates special components relating the responsibility for the illegal capturing and trafficking of valuable wild animals listed in the Red Data Book (Article 258.1). Turnover ability (a possibility of transition from one person to another according to the transaction) of wild animals belonging to the species listed in the Red Data Book of the Russian Federation is admitted in exceptional cases according to the permit (administrative license) issued by specially authorized state authority for protection of the environment.

Other inalienable legal rights of animals listed in the Red Data Book of any level is the right to freedom of movement, a kind of which is the right to freedom from illegal contraband capturing and export abroad. The latter act implies criminal liability in the Russian (Article 226.1). In addition, the right to natural habitat should be highlighted. In case of destruction of habitats of organisms listed in the Red Data Book causing death of the populations of these organisms the guilty persons are brought to criminal responsibility (Article 259).

2) Wild animals referred to hunting. These animals are usually included in special lists and the number of licenses for their shooting (capture) depends on their population. Therefore, these animals have no right to life or to preservation of the natural habitat. At the same time, laws of most countries establish criminal liability for illegal capturing (without a license) of objects of wildlife - poaching (Article 258 in the Criminal Code of the Russian Federation). This category of wild animals, like the previous one, has the right to freedom of movement and freedom from contraband capturing and export abroad.

The citizens' right to hunting is not absolute; it is limited by the rights of animals to humane hunting methods including those with the use of traps. For example, on November 4, 1991, the Council of the European Community adopted Regulation No. 3254/91 prohibiting the use of leghold traps in the Community and introduction into the Community of pelts and manufactured goods of certain wild animal species originating in countries which catch them by means of leghold traps or trapping methods which do not meet international humane trapping standards. In Russia, the mandatory compliance of tools and methods of hunting with the international standards of humane capturing of wild animals is stipulated by Part 2 Article 22 Law of the Russian Federation of July 24, 2009, No. 209-FZ "On Hunting, Preservation of Hunting Resources and on Amendments to Certain Legislative Acts of the Russian Federation". Moreover, such bans follow from the Agreement on International Humane Trapping Standards concluded between the Russian Government, the 
European Community and the Government of Canada in 1997. Signing this Agreement, the Russian Government issued a Statement on a special ban on the use of standard leghold restraining traps with steel arches.

However, international standards for humane trapping are designed only for 2 types of traps and only for 19 species of fur animals; the Hunting Rules do not stipulate which of the hunting method restrictions introduced are associated with the principle of humanity. A more detailed study of these restrictions leads to the conclusion that they are established mainly to preserve the population of wild animals and ensure the safety of people.

3) Wild animals ignored by the law. These are wild animals not included in the Red Data Book and not mention with respect to hunting. In contrast to these two groups, there is no clear list of species of the group under consideration. This group may include lizards, hamsters, hedgehogs, snakes, frogs, some species of birds, etc. According to Article 43 of the Russian Law “On Fauna”, capturing of fauna items not referred to hunting resources and aquatic biological resources is allowed only on the basis of licenses of specially authorized state authorities for protection, control and regulation of use of fauna and habitats. Therefore, their legal status resembles game animals, but it is less clear and there are no guarantees of the rights of this group of animals in Russian law.

It follows from this review that the scope of legal rights of wild animals is similar to domestic animals and varies in different groups. The widest scope of these rights is observed with wild animals included in the Red Data Book. Some guarantees of humane treatment (capturing and trapping) is stipulated for game animals (prohibition or a special type of traps killing immediately with avoiding suffering). Small animals with the most lack of rights are placed into the third group. Consequently, different groups of wild animals have no equality in their rights.

\section{DEVELOPMENT OF VIEWS ON ANIMAL RIGHTS: A BRIEF COMPARATIVE HISTORICAL ANALYSIS}

Views on animal rights developed with the same dynamics and with the use of the same stereotypes as development of human rights. Slaves of Ancient Rome had no legal rights as well as animals. However, the inefficiency of slave labor led to provision of slaves with a peculium, i.e. a land plot, for which the owner had to pay a certain share of products (usually half of the crops). By the end of the Empire unauthorized killing of slaves, separation of their families was prohibited, the procedure of their release was simplified.

In "barbarian states" which emerged from the ruins of the Roman Empire, the dynamics of different scope of legal personality of various groups of population can even more clearly be observed. Salian Law stipulated the following social structure of the Frankish society: secular lords represented by the new servile aristocracy; clergy; free Franks-peasants (the most part of the population of the country); liti - semifree; GalloRomans, slaves. Free Franks were engaged in agriculture and lived in neighboring communities - marks, constituting the basis of the social organization. ${ }^{39}$

Early feudal England had different legal statuses of villeins (serf members of rural communities, the main part of the dependent population); cotters (land-poor farmers working for feudal lords or rich peasants); freeholders (free holders of land plots that they could alienate and had the right to protection in the royal courts). ${ }^{40}$

39 Kanaev (2005).

40 Vinokurova (2009). 
In Germany, in the times of early feudalism there were such categories of feudaldependent population as manicipiums, serfs, precariums and allodists (Reading book on history of the Middle Ages 1961).

A similar trend is observed in Kievan Rus (IX-XI centuries), with different social statuses of peasants, town dwellers (merchants, craftsmen), clergy and feudal lords (boyars and nobles). Peasants (smerds) were divided into free and dependent. Those who became dependent having taken a kupa (debt) were called zakups. Those who became dependent after conclusion of a ryad (agreement) were called ryadoviches. Impoverished persons from communities were izgoys, and kholops were actually slaves.

A similar difference in the scope of legal rights of certain categories of people typical of the era of early feudalism can now be observed with respect to different categories of wild and domestic animals. Law here has absolutely nothing to do with - it only reflects, as best it can, the prejudices and superstitions in the mass public consciousness of modern society. The history of feudalism showed how the gradual inevitable consolidation of separate social groups in wider social communities (classes in Marxism). The same things will happen to the legal status of animals. It was after the English bourgeois revolution of the 17th century and the Great French Revolution of the18th century, when the first generation of universal human rights (of all people, without division into groups) emerged, the peaceful public burst of human legal conscience will take place, as a result of which generations of universal animal rights will emerge. Undoubtedly, animals simply do not need most of universal human rights (for example, why do cats or cows need political rights?). However, the above mentioned various personal rights of animals are universal and they deserve full protection.

\section{NEW RIGHTS OF ANIMALS AS ONE OF THE CHALLENGES OF THE $21^{\text {th }}$ CENTURY}

The previous analysis looked animal rights which are directly or indirectly stipulated by the legislation or actually exercised without this direct stipulation. For this reason, the majority of the animals' rights identified by us are known in general; some were even discussed by scientists and politicians with a positive regulatory result. Hereafter we will try to state potential animal rights which are not recognized in Russia and other post-Soviet countries.

1) Domestic animals should be granted the status of a special subject of civil law instead of the current status of "a special subject of civil law". The animals do not need many rights which compose the legal competence of citizens (right to business activity). They either exercise other property and personal non-property rights (author's right, right to inherit property) in some countries or it will be possible in practice in the future. Undoubtedly, the question is only about legal competence of animals, but not about their legal capacity. The rights of domestic animals may be exercised only by the animals' owners or other interested parties. Moreover, animals may not have obligations and be legally liable. In this case, their legal position resembles the position of the other special groups of subjects of civil law - infants or incapable adults.

2) There is both legal regulation (Articles 231-232 Civil Code of the Russian Federation) and practice of its application with respect to taking into account the animal's opinion (the possibility of choice of neglected domestic animals between the previous and new owners). This concept should be further developed considering animal interests, their attraction and possibilities of the owners to keep them in case of division of property (animals) between the spouses during divorce. 
3) The legal status of the subject of law may not be given to all species of animals at once but gradually to some of them. The following species of animals may be mentioned among such animals: chimpanzee and other species of anthropoid apes which are characterized both by complicated nervous system and emotions, in any case, not less than human children and incapable citizens have. In particular, the law adopted in New Zealand led to fundamental changes in the legal system of the country, extended main rights of the nearest evolutional relatives of mankind. Now, according to the law, these animals hold three main rights: The right to life; the right to protection against cruelty and the right not to be subject to medical and scientific experiments.

4) In Russia, it is reasonable to solve the problem of protection of animal rights at the federal but also at the regional level. For this purpose, it is necessary to adopt a framework federal law containing main animal rights which should be specified by every region due to historical and cultural, geographical and other peculiarities.

5) The gradual replacement of the anthropocentrical model of interaction of man and animals will result in many particular step-by-step actions, e.g., the limitation and then prohibition of sport hunting, when animals are killed not for the purpose of human survival but for pleasure. In a similar way, the field of use of circuses and zoos, medical experiments against animals, sport entertainment with participation of animals will be reduced. Now it looks like fiction, but did it seem possible to recognize electoral rights of women not long ago?

The necessity of adoption of laws on protection of animal rights should be stipulated not only by pity and sympathy for "our relatives" but by moral and ethical reasons associated with the fact that the prohibition of animal agony makes it possible to form a more morally healthy young generation which will not offend children and old people.

\section{CONCLUSIONS}

Nowadays, the majority of legal animal rights is not enshrined anywhere, although is actually available and applied in practice. Meanwhile, the scope of these rights is very different both in groups of wild and domestic animals and inside each group according to objective (national social and cultural, legal and other) and subjective factors (will of a certain owner of a domestic animal). It is the total Utopia at the moment to call for creation of some abridgement of unified and universal rights for all groups and categories of animals. In this regard, the goal of scientists, politicians and indifferent public should be different: lobbying of stipulation of available legal animal rights in the International Convention for Animal Rights; national development and adoption of the Law "On Protection of Animal Rights" which specifies these rights and the mechanism of their exercise according to the national specifics. At the same time, a new category of subjects of law - animals, the guardians of which are citizens (owners) or legal entities (public ecological associations or authorized agencies, e.g., wild animals) should emerge in the Civil Codes of the interested states. Only then is it necessary to go on to the next step associated with the further extension of legal personality of certain representatives of fauna, for example, anthropoid apes. However, this movement will be very slow and gradual. Everything will develop in the same way as human rights developed in the age of early feudalism. 


\section{LITERATURE}

Appellate Decision of Altai Krai Court of 04.12.2013 No. 33-9800-13. Legal Reference System "Consultant Plus" accessed 27 May 2016.

Benthall, J., 'Animal Liberation and Rights' (2007) 23-2 Anthropology Today 1-3.

Bocharov, E.V., Criminal Liability for Cruelty to Animals (Candidate thesis, Moscow State Linguistic University 2014).

Branham A., 'Detailed Discussion of Philosophy and Animals' (Fall edn, 2005) <https://www. animallaw.info/article/detailed-discussion-philosophy-and-animals> accessed 27 May 2016.

Brophy, B., 'The Rights of Animals' (1965) Sunday Times, $10^{\text {th }}$ October.

City cemetery for animals <http://городскоекладбищеживотных.pф/reglament/> accessed 27 May 2016.

Descartes, R., Meditations on First Philosophy with Selections from the Objections and Replies (Cambridge University Press 1996).

De Waal, F., 'We the People (and Other Animals)' (1999) New York Times, $20^{\text {th }}$ August.

Cottingham J., 'A Brute to the Brutes? Descartes' Treatment of Animals' (1978) 53-206 Philosophy $551-9$.

Favre, D., 'Judicial Recognition of the Interests of Animals. A New Tort' (2005) 333 Michigan State Law Review 334-66.

Frazer, J., Folklore in the Old Testament (Varda Books 2001).

Garrison, J., 'A Call to Attorneys: Brainstorming to Help Captive Elephants' (1998) 16 Pace Environmental Law Review 133-8.

Batyr, K.I. (ed), 'General History of State and Law' (Bylina 1995).

Gibson, H., 'Detailed Discussion of Dog Fighting' (Fall edn, 2005) < https://www.animallaw.info/ article/detailed-discussion-dog-fighting> accessed 27 May 2016.

Grech, K.S., 'Detailed Discussion of the Laws Affecting Zoos' (Fall edn, 2004) <https://www. animallaw.info/article/detailed-discussion-laws-affecting-zoos> accessed 27 May 2016.

Haas, A., 'Interpreting "Enhancement of survival" in Granting Section 10 Endangered Species Act Exemptions to Animal Exhibitors' (2005) 32 Pace Envtl. L. Rev. 956-60.

Hilden, J., 'A Contractarian View of Animal Rights: Insuring against the Possibility of Being a Nonhuman Animal' (2007) 14 Animal Law 5-28.

Hume, D., A Treatise of Human Nature (first published 1738-40, Hard Press 2006).

Kanaev, A.G., History of State and Law. Frankish State: Lecture (Siberian Law Institute of the Ministries of Internal Affairs of Russia 2005).

Kant, I., Anthropology from a Pragmatic Point of View (first published 1798, Southern Illinois University Press 1978).

Kant, I., Lectures on Ethics (first published 1924, Republic 2000).

Lovvorn, J.R., 'Animal Law in Action: the Law, Public Perception, and the Limits of Animal Rights Theory as a Basis for Legal Reform' (2006) 12 Animal law 133-49.

Neumann, J., 'Redefining the Modern Circus: a Comparative Look at the Regulations Governing Circus Animal Treatment and America's Neglect of Circus Animal Welfare' (2014) 36 Whittier L. Rev. 167-94.

Order of the State Committee for Environmental Protection of the Russian Federation of 19.12.1997 No. 569 (revised on 28.04.2011) "On Approval of Lists of Objects of Fauna Listed in the Red Data Book of the Russian Federation and Excluded from the Red Data Book of the Russian Federation". Legal Reference System "Consultant Plus" accessed 27 May 2016.

Petukhova E.P., Constitutional Legal Regime of Natural Resources (Candidate thesis, National Research University "Higher School of Economics" 2015).

Skazkina, S.L. (ed), 'Reading Book on History of the Middle Ages. Early Middle Ages' (Publishing house of social and economic literature 1961).

Regan, T., The Case for Animal Rights (3rd edn, U. Cal. Press 2004).

Regan, T., 'The Day May Come: Legal Rights for Animals' (2004) 10 Animal Law 11-24.

Satz, A.B., 'Animals as Vulnerable Subjects: Beyond Interest-convergence, Hierarchy, and Property' (2009) 16 Animal law 65-122. 
Sætra, H., 'The State of no Nature - Thomas Hobbes and the Natural World' (2014) 8 Ecology \& Safety $177-93$.

Scheiner, C., "“Cruelty to Police dog” Laws Update' (2001) 7 Animal law 141-4.

Singer, P., Animal Liberation: A New Ethics for our Treatment of Animals (New York Review/Random House 1975).

Thomas, B.L., 'Antimony: The Use, Rights, and Regulation of Laboratory Animals' (Fall edn, 1986).

$<$ https://www.animallaw.info/article/antimony-use-rights-and-regulation-laboratory-animals $>$ accessed 27 May 2016.

Vinokurova, M.V., "Issue of "the Last Villainage" in England of the XVI Century in Russian Historiography' (2009) 9-1.

Wise, S., Rattling the Cage: Toward Legal Rights for Animals (Perseus Books 2000).

Wise, S., Drawing the Line: Science and the Case for Animal Rights (Perseus Books 2002).

World Charter for Nature. Adopted by Resolution No. 37/7 of the UN General Assembly of October 28, 1982. <http://www.un.org/ru/documents/decl_conv/conventions/charter_for_nature.shtml> accessed 27 May 2016.

\section{LINKS}

1. Biological Encyclopedic Dictionary (Soviet Encyclopedia 1986) $<$ http://www.bioword.narod.ru/ G2/G2054.htm> accessed 27 May 2016.

2. Hobbes, T., Leviathan or the matter form and power of a commonwealth Ecclesiaastical and civil (University of Adelaide 2016) <https://ebooks.adelaide.edu.au/h/hobbes/thomas/h681/complete. html > accessed 27 May 2016.

3. Pavlova, T.N., Movement for animal rights (Fall edn, 1998) $<$ http://westernizer.com/index/0-80> accessed 27 May 2016. 